\title{
Effects of Licorice on Some Selected Properties of Ice Cream
}

\section{Meyan Kökü İlavesinin Dondurmanin Bazı Özellikleri Üzerine Etkisi}

\section{Research Article}

\author{
Ibrahim Hayoğlu'1*, Şerafettin Çelik', Hüseyin Turkoğlư², Bülent Başyiğit', Naciye Ünver ${ }^{1}$ \\ 'Department of Food Engineering, Agricultural Faculty, Harran University, Sanliurfa, Turkey. \\ Ula Ali Koçman Vocational High School, Mugla University, Mugla, Turkey.
}

\section{A B STR ACT}

icorice is used in food industry including production of candy and confectionary, for its healthy and taste _ characteristics, as well as technological properties. We attended to produce a new ice cream variety using licorice to increase consumption and provide an alternative taste in dairy industry. In addition to control (without licorice extract), four levels of licorices $(0.5 \% \mathrm{~A}, 1.0 \% \mathrm{~B}, 1.5 \% \mathrm{C}, 2.0 \% \mathrm{D})$ were added to the mixture. Licorice improved especially overrun, color and overall acceptability of ice cream. Considering physical, chemical and sensory properties, addition of licorice up to $1.5 \%$ was convenient for an attractive ice cream production.

\section{Key Words}

Color, ice cream, licorice, sensory.

\section{Ö z}

$\mathrm{M}$ eyan kökü teknolojik özelliklerinden, sağlık üzerine etkilerinden ve tadından dolayı gıda endüstrisinde kullanıımaktadır. Çalışmada meyan kökü kullanılarak farklı tatta yeni bir dondurma üretimi yapılmıştır. Karışıma \%0.5 A, \%1.0 B, \%1.5 C, \%2.0 D oranlarında meyan kökü ilavesi yapılarak elde edilen sonuçlar kontrol (meyan kökü içermeyen) örnek ile karşılaştırılmıştır. Meyan kökü dondurmanın renk ve genel kabul edilirliği gibi özellikerini geliştirdiği gözlemlenmiştir. Dondurma içerisine \%1.5'e kadar meyan kökü ilavesinin istenilen fiziksel, kimyasal ve duyusal özellikere sahip dondurma için uygun olduğu belirlenmiştir.

\section{Anahtar Kelimeler}

Renk, dondurma, meyan kökü, duyusal.

Article History: Received: Mar 8, 2017; Revised: Jul 20, 2017; Accepted: Oct 12, 2017; Available Online: Dec 25, 2017. DOI: 10.15671/HJBC.2018.176

Correspondence to: i. Hayoğlu, Department of Food Engineering, Agricultural Faculty, Harran University, Sanliurfa, Turkey. Tel: +90 4143183721 


\section{INTRODUCTION}

ecently ice cream science and technology has undergone a remarkable progress exploring and understanding structure, texture and storage stability. This has enabled food technologists to fairly realize the incorporation of novel or functional ingredients in ice cream systems in order to not only provide customized techno functionality such as viscosity enhancement, cryoprotection etc., but also to improve healthrelated and nutritional aspects [1].

The main component of licorice extract is glycyrrhizic acid and glycyrrhizin, and they occur naturally in the root of the licorice plant. The unique properties of this compound have led to the surprising number of food products that contain licorice: medicines such as cough syrups, herbal supplements, tobacco, drinks, and candies. It is also used as a herbal medicine for its therapeutic properties such as anti-carcinogenic, antiviral, radio-protective, anti-inflammatory properties, to eliminate phlegm, relieve spasm, cough, alleviate pain, and moderate the potency of drugs remedy for the treatment of bronchial asthma, eczemas and etc [2-7].

Our objective was to develop a new ice-cream variety, enhanced the functional properties, by adding licorice extract at different concentrations and evaluates their organoleptic and some quality characteristics. So, developing a new ice cream formulation with new flavor appears to be an alternative way to increase milk consumption.

\section{MATERIAL and METHODS}

\section{Material}

Commercial solid blocks of licorice that granted by Ramco (Ra-Ma Bayrakdar Licorice Root Industry $\&$ Trading Ltd. Co. Kilis, Turkey) were used in ice cream formulation. The selected characteristics of licorice used in study were as follow: moisture $2 \%$, ash $9 \%$, glycyrrhizin $30 \%$, sucrose $10 \%$ and acidity $5.6 \mathrm{pH}$.

\section{The Production of Experimental Ice Cream}

Experimental ice cream mixes were performed to contain $8 \%$ milk fat. The mixture including 150 g cream (35\% fat), $180 \mathrm{~g}$ sugar, $10 \mathrm{~g}$ gum, $20 \mathrm{~g}$ skimmilk powder was dissolved in one liter of milk (3\% fat), pasteurized at $85^{\circ} \mathrm{C}$ for $25 \mathrm{~min}$., and then cooled. The mix was divided into five parts: Control without licorice extract, $0.5 \%, 1.0 \%, 1.5 \%$, $2.0 \%$ of licorice extract was added to the other mixture respectively. Then the mixtures were aged for $12 \mathrm{~h}$ at $4^{\circ} \mathrm{C}$. Ice creams were produced using laboratory type ice-cream machine (Simac II Gelatatio GC 6000), packed in $100 \mathrm{~g}$ portions and hardened at $-20^{\circ} \mathrm{C}$.

\section{Physicochemical Analysis}

The ice cream mix samples were analyzed for drymatter, ash, acidity (titratable acidity and pH) [8] viscosity (Brookfield Programmable DVII+Viscometer, UK) [9] and first dropping time [10]. On the other hand, ice cream samples were also determined for overrun and penetrometer values (Sur-Berlin PNR6-496 model penetrometer [9].

\section{Color Analysis}

The color of ice cream samples was measured with Color Quest XE color difference meter [11].

\section{Sensorial Analysis}

Samples were organoleptically evaluated by a panel 10-member trained assessor of the Food Engineering Department of Harran University for appearance, texture and flavor using a 10-point scale, scoring 1 for the worst and 10 for the best.

\section{Statistical Analysis}

The trial was arranged according to factorial design in completely randomised blocks. The data obtained were subjected to one-way ANOVA, the significant differences were tested using Duncan multiple ranges test to determine the differences among treatments [12]. A root square conversion was applied to sensorial data before statistical analysis. The study was carried out in triplicate, while the analysis was done in duplicate.

\section{RESULTS and DISCUSSIONS}

\section{Some Physiochemical Properties of Ice Cream}

In preliminary studies, up to $10 \%$ licorice extract were used in the production of ice cream. It was observed that the physicochemical parameters evaluated of the ice cream getting worst after $2 \%$ 
licorice extract addition to mix. Indeed, licorice flavor becomes extremely dominant and the darkening of color, taste and overall acceptability of the samples decreases were reported in the samples containing more than $2 \%$ licorice by the panelists. Therefore, maximum licorice extract addition was limited as $2 \%$.

Some physicochemical properties of experimental ice cream samples are given in Table 1. Statistically significant differences were obtained between control and licorice extract added ice cream with regard to drymatter, viscosity, overrun and penetrometer value. Drymatter contents of licorice extract added ice cream samples were statistically not different from each other, but they were significantly $(p<0.05)$ lower than the control. Also drymatter content of samples decreased with the increase of licorice content. This is likely due to the high water holding capacity of licorice. Addition of licorice caused a slightly increase in ash content, but this was not statistically significant. Likewise, the changes in acidity and $\mathrm{pH}$ values were not statistically significant.

The first dropping time decreased with increased licorice addition; however it was statistically not significant. This may have arisen from the increase in soluble solids content, and consequently changes in freezing point of mixture. Similarly, [13] reported that at any given fat level of ice cream, the time to
$50 \%$ melt decreased as sugar content increased.

Viscosity of ice cream samples showed similar tendency both at 20 and $50 \mathrm{rpm}$. As can be seen in Table 1, the viscosity values increased significantly $(p<0.05)$ with increased amounts of licorice extract addition. The increase in viscosity is considered as a result of increase in water holding capacity of ice cream, related with licorice extract addition. In contrast, the viscosity of ice cream added Saffron [14] or some other additives (Cacao, Caramel, Coffee or their dual mixtures) were found lower than the control $[15,16]$ stated that binding water by hydrophilic terminus of emulsifiers resulted in less water to freeze, therefore caused formation of smaller ice crystals.

Licorice extract addition increased penetrometer and overrun values of ice cream significantly $(p<0.05)$. Also, [14] determined that the addition of Saffron to the ice cream mix resulted in higher overrun ratio with respect to the control. As overrun value increases, the density of ice cream gets lower and the texture gets softer, which cause the penetrometer value to increase. Overrun refers to increase in volume caused by air incorporation into mix during freezing process. Incorporation of air into the mix changes the density, eating attributes, appearance, and taste of ice cream. Lower amount of air in mixture brings about a denser, heavier and colder ice cream, whereas, higher amount of

Table 1. Some physicochemical properties of ice cream samples.

\begin{tabular}{cccccc}
\hline Parameter & Control & A & B & C & D \\
\hline Drymatter (\%) & $36.39 \mathrm{~b}$ & $33.87 \mathrm{a}$ & $34.11 \mathrm{a}$ & $34.08 \mathrm{a}$ & $34.38 \mathrm{a}$ \\
\hline Ash (\%) & 0.86 & 0.88 & 0.93 & 1.02 & 6.43 \\
\hline $\mathrm{pH}$ & 6.50 & 6.48 & 6.47 & 6.45 & 0.25 \\
\hline $\begin{array}{c}\text { Titretable } \\
\text { acidity (\%) }\end{array}$ & 0.23 & 0.21 & 0.22 & 0.24 & 31.0 \\
\hline $\begin{array}{c}\text { First dropping } \\
\text { time (min) }\end{array}$ & 41.0 & 36.5 & 36.5 & 35.5 & $893.33 \mathrm{c}$ \\
\hline $\begin{array}{c}\text { Viscosity 20 } \\
\text { rpm }\end{array}$ & $603.33 \mathrm{a}$ & $566.67 \mathrm{a}$ & $773.33 \mathrm{~b}$ & $880.00 \mathrm{c}$ & $583.33 \mathrm{c}$ \\
\hline $\begin{array}{c}\text { Viscosity 50 } \\
\text { rpm }\end{array}$ & $413.33 \mathrm{a}$ & $405.33 \mathrm{a}$ & $533.33 \mathrm{~b}$ & $576.00 \mathrm{c}$ & $103.00 \mathrm{~d}$ \\
\hline \begin{tabular}{c} 
Penetrometer \\
\hline \begin{tabular}{l} 
Overrun (\%) \\
\hline
\end{tabular}
\end{tabular} & $74.00 \mathrm{a}$ & $75.33 \mathrm{a}$ & $82.00 \mathrm{~b}$ & $91.67 \mathrm{c}$ & $66.34 \mathrm{e}$ \\
\hline
\end{tabular}

Level of licorice extract addition A: 0.5\%; B: 1.0\%; C: 1.5\%; D: 2.0\%. The means in the same lines followed by different letters are significantly different $(p<0.05)$. 
Table 2. The mean values of color parameters of ice cream samples.

\begin{tabular}{cccccc}
\hline Parameter & Control & A & B & C & D \\
\hline L* value $^{*}$ & 63.97 & 57.11 & 40.46 & 35.30 & 27.04 \\
\hline a* value & -0.46 & 2.83 & 4.05 & 4.74 & 6.23 \\
\hline b* value & 11.65 & 21.18 & 21.36 & 21.77 & 25.99 \\
\hline dE value & 37.68 & 35.30 & 23.04 & 20.37 & 31.36 \\
\hline C* value & 11.7 & 21.4 & 79.3 & 22.3 & 26.7 \\
\hline h* value & -87.7 & 82.4 & 77.7 & 76.5 \\
\hline
\end{tabular}

Level of licorice extract addition A: 0.5\%; B: 1.0\%; C: 1.5\%; D: 2.0\%. The means in the same lines followed by different letters are significantly different $(p<0.05)$.

air makes it lighter, and felt creamy and warmer in mouth. Ice cream with optimum overrun is dry in appearance. Air in ice cream provides a light texture, and influences its physical properties especially melting down and hardness. However, it is not just the amount of air incorporated, or overrun, but also the distribution of sizes of the air cells that influences these parameters. The manufacture of high quality ice cream requires careful control of both overrun and air cell size distribution [17].

Licorice extract addition of $2 \%$ almost doubled the volume of ice cream. Overrun is one of the most important quality criteria of ice cream, caused by air trapped in the ice cream body. Licorice found widespread usage as a foaming agent in alcoholic and non-alcoholic beverages [18]. So we can conclude that addition of licorice into formulation improved viscosity, penetrometer value and overrun of ice cream.

The fat structure in ice cream is affected by a complex combination of composition, manufacturing processes and methods and also machine properties. One of the most important factors is homogenisation. Homogenisation is a manufacturing process that reduces the size of fat particles and forms a homogeneous fat

Table 3. Mean values of sensory characteristics of ice cream samples.

\begin{tabular}{|c|c|c|c|c|c|}
\hline Parameter & Control & $A$ & B & C & D \\
\hline Color $(p<0.01)$ & $1.16 a$ & $1.70 b$ & $2.08 c$ & $2.30 \mathrm{~d}$ & $2.45 \mathrm{de}$ \\
\hline Texture and viscosity & 2.60 & 2.66 & 2.36 & 2.45 & 2.55 \\
\hline $\begin{array}{l}\text { Rough structure } \\
\qquad(p<0.01)\end{array}$ & $1.25 a$ & $1.48 a$ & $2.18 b$ & $1.45 a$ & $1.20 \mathrm{a}$ \\
\hline Gumminess & 1.37 & 1.41 & 1.47 & 1.38 & 1.34 \\
\hline Iceness & 2.87 & 2.92 & 2.84 & 2.81 & 2.89 \\
\hline Melting & 2.71 & 2.75 & 2.77 & 2.75 & 2.71 \\
\hline $\begin{array}{l}\text { Taste and aroma } \\
\qquad(p<0.05)\end{array}$ & $2.82 a$ & $2.80 a$ & $2.74 a b$ & $2.52 b$ & $2.49 b$ \\
\hline $\begin{array}{l}\text { Sensation in mouth } \\
\qquad(p<0.10)\end{array}$ & $2.77 a$ & $2.72 \mathrm{a}$ & $2.71 \mathrm{a}$ & $2.54 a b$ & $2.39 b$ \\
\hline Sweetness & 2.33 & 2.40 & 2.44 & 2.42 & 2.40 \\
\hline Off flavor & 2.71 & 2.68 & 2.76 & 2.49 & 2.37 \\
\hline $\begin{array}{l}\text { Resistance to } \\
\text { melting (at ambient } \\
\text { temperature) }\end{array}$ & 2.49 & 2.48 & 2.45 & 2.40 & 2.31 \\
\hline $\begin{array}{l}\text { Overall acceptability } \\
\qquad(p<0.10)\end{array}$ & $2.76 a$ & $2.75 a$ & $2.73 a$ & $2.57 a b$ & $2.43 b$ \\
\hline
\end{tabular}

Level of licorice extract addition A: 0.5\%; B: 1.0\%; C: 1.5\%; D: 2.0\%. The means in the same lines followed by different letters are significantly different $(p<0.05)$. 
emulsion in ice cream. In general, homogenization reduces the size of fat particles to less than $2 \mu \mathrm{m}$ and increases the number and surface area of fat particles [19]. Because of networks of fat globules were not formed in the nonhomogenised ice cream, it was hard, had low resistance to meltdown, and ice crystals grew rapidly in it. In contrast, the ice cream samples homogenised at $5 \mathrm{MPa}$ or more grew harder and had higher resistance to meltdown as homogenisation pressure increased. Thus the quality of ice cream could be preserved during storage, and it was recommended homogenization at $10 \mathrm{MPa}$ to produce stable structure for high-fat ice cream [20].

\section{Color Parameters of Ice Cream}

Addition of licorice significantly $(p<0.05)$ affected the color, taste and aroma, sensation in mouth and general acceptability of the ice cream samples studied (Tables 2 and 3). Due to dark brownish colour of licorice, the color intensity of ice creams increased significantly $(p<0.05)$ with increasing licorice percentage.

Colour of samples became darker with increased percentage of licorice added; however, this was not an irritating change. The effect of licorice on the perceived color of samples by human eye could clearly be seen (Table 3 ). In parallel to visual detection, the instrumental measurements also showed the brown color imparted to the samples. With increased amounts of licorice in formulation, $a^{*}$ and $b^{*}$ values of samples increased but $L$ value decreased (Table 2).

\section{Sensorial Parameters of Ice Cream}

Roughness of ice cream samples was similar to that of control except for sample B. The assessors perceived less rough texture only in sample B. According to sensory evaluations, the gumminess, iciness and melting characteristics were not significantly ( $p>0.05$ ) affected by licorice addition. Iciness and melting rate of ice cream are generally decreased with increased fat content. Iciness also decreases with the increase of sugar doses. However, objectionably iciness is reported to be caused by high levels of high fructose corn syrup as sweetener or high guar to locust gum ratio [21].

Perception in the mouth (sensation in mouth) was not significantly affected up to $1.5 \%$ licorice extract level; beyond this point intense caramelish licorice aroma were perceived. However, those assessors who were familiar with licorice aroma liked the ice cream even with $2 \%$ licorice.

The sweetness score of ice creams were statistically not different from each other; however it increased with increased licorice content as a result of sweet compound, glycyrrhizin. Glycyrrhizin is a sweet-tasting triterpene saponin isolated from the Glycyrrhiza plant, which is a conjugate of 2 molecules-glucuronic acid and glycyrrhetinic acid (an oleanane-type triterpene). Glycyrrhizin has a longlasting sweetness and is approximately 150-200 times sweeter than sucrose [22-23].

None of the samples had any off flavor. The addition of licorice did not have any significant effect on resistance to melting characteristics of ice cream samples.

Considering overall acceptance characteristics, ice cream samples with licorice up to $1.5 \%$ were similar to control, which was the most-liked sample, beyond this point, the score decreased significantly $(p<0.05)$ because of marked licorice taste. [15] found that adding some additives (Cacao, Coffee, Caramel or their dual mixes) to ice cream positively affected the sensorial properties of ice cream. On the other hand, [24] stated that ice cream containing $0.75 \%$ Cola exract and Cola flovour could be used in the production of ice cream. In another study, it was found that maltitol (85\%) syrup as a natural sweetener could be substituted in the production of diabetic type ice cream, all examined physicochemical properties of the ice cream found nearly similar to the control [25]. Çelik et al. concluded that Saffron could be used in the production of plane and diabetic ice cream types because of determined positively effects on ice cream properties such as color, taste and overrun [14].

\section{CONCLUSIONS}

The results of the present study showed that licorice extract could be successfully used in ice cream production. The addition of licorice extract into formulation affected overrun, taste and aroma, color and sensory properties of ice cream. 
Licorice extract addition significantly improved viscosity, penetrometer and overrun values of ice cream. The samples with up to $1.5 \%$ licorice were comparable to control ice cream based on overall acceptability. In addition, color of samples was preferred up to $1.5 \%$ licorice addition. It can be concluded that up to $1.5 \%$ of licorice could be incorporated into ice cream mix. On the other hand, licorice could be used in the production of ice cream to prevent undesirables color, taste and odor especially in some probiotic bacteria added ice cream types.

\section{ACKNOWLEDGEMENTS}

The author would like to thank Prof. Dr. A. R. Mermut, from the University of Saskatchewan, Faculty of Agriculture in Saskatoon, Canada for his critical review, comments, and suggestions.

\section{References}

1. C. Soukoulis, I.D. Fisk, and T. Bohn, Ice Cream as a Vehicle for Incorporating Health-Promoting Ingredients: Conceptualization and Overview of Quality and Storage Stability. Comprehensive Reviews, Food Sci. Food Safety., 13 (2014) 627-655.

2. G.A. Tolstikow and V.A. Mytkin, Complex of glycerrhetinic acid with methyluracyl- a new class of antydotes and antiradicals drugs. In: Investigation and Using of Licorice Roots in Medicine, Alma Ata Talym Press, 196p. 1991.

3. S. Shibata, A drug over the millennia: pharmacognosy, chemistry, and pharmacology of licorice, Yakugaku Zasshi., 120 (2000) 849-862.

4. S. Christie, A.F. Walker and G.T. Lewith, Flavonoids-a new direction in the treatment of fluid retention, Phytother. Res., 15 (2001) 467-475.

5. P.G. Kovalenko, V.P. Antonjuk and S.S. Maliuta, Secondary metabolites synthesis in transformed cells of Glycyrrhiza glabra L. and Potentilla alba L. as producents of radioprotective compounds, Ukrainica Bioorganica Acta., 1 (2004): 13-22.

6. C. Fiore, M. Eisenhut, R. Krausse, E. Ragazzi, D. Pellati, D. Armanini and J. Bielenberg, Antiviral effects of Glycyrrhiza species, Phytotherapy Res., 22 (2008) 141-148.

7. J.C. Lin, J.M. Cherng, M.S. Hung, L.A. Baltina and R. Kondratenko, Inhibitory effects of some derivatives of glycyrrhizic acid against Epstein-Barr virus infection: Structure-activity relationships, Antiviral Res., 79 (2008) 6-11.

8. R.T. Marshall, "Standard Methods for the Examination of Dairy Products" (16 $6^{\text {th }}$ Edition), American Public Health Assoc, Washington D.C. USA. 1992.
9. M. Dervisoglu, Influence of Hazelnut Flour and Skin Addition on the Physical, Chemical, and Sensory Properties of Vanilla Ice Cream, Int. J. Food Sci. Tech., 41 (2006) 657-661.

10. J.F.L. Cotrell, G. Pass and G.O. Phillips, Assesment of Polysaccharides as Ice Cream Stabilizers, J. Sci. Food Agric., 30 (1979) 1085-1089.

11. Anonymous. The Basics of Color Perception and Measurement. Hunterlab Presents, Reston VA, USA 2001.

12. SAS INSTITUTE, SAS/STAT, SAS Inst, Cary, NC, USA 2000.

13. J.X. Guinard, C. Zoumas-Morse, L. Mori, B. Uatoni, D. Panyam and A. Kilara, Sugar and Fat Effects on Sensory Properties of Ice Cream, J. Food Sci., 62 (1997) 1087-1094.

14. S. Celik, H. Cankurt, C. Doğan, Safran ilavesinin sade dondurmanın bazı özelliklerine etkisi, Gıda., 35 (2010) 33-39.

15. E. Dagdemir, C. Ozdemir, S. Celik, S. Ozdemir, Determination of some properties of caramel cocoa and coffee flavored ice creams. International Dairy Symposium, May (24-28), Isparta, Turkey. 2004.

16. R.J. Baer, M.D. Wolkow and K.M. Kasperson, Effect of Emulsifiers on the Body and Texture of Low Fat Ice Cream, J. Dairy Sci., 80 (1997) 3123-3132.

17. R.P. SOFJAN and R.W. Hartel, Effects of overrun on structural and physical characteristics of ice cream, Int. Dairy J., 14 (2004) 255-262.

18. E. Ibanoglu and S. Ibanoglu, Foaming behaviour of liquorice (Glycyrrhiza glabra) extract, Food Chem., 70 (2000) 333-336

19. R.T. Marshall, H.D. Goff and R.W. Hartel, Ice Cream ( $6^{\text {th }}$ edition). Kluwer Academic/Plenum Publishers, New York, 2003.

20. M. Tosaki, Y. Kitamura, T. Satake and T. Tsurutani, Effects of homogenisation conditions on the physical properties of high-fat ice cream, Int. J. Dairy Technol., 62 (2009) 577-583.

21. S.A. Wittinger and D.E. Smith, Effect of sweeteners and stabilizers on selected sensory attributes and shelf life of ice cream, J. Food Sci., 52 (1986) 14631466.

22. K. Mizutani, T. Kuramoto, Y. Tamura, N. Ohtake, S. Doi, M. Nakaura and O. Tanaka, Sweetness of glycyrrhetinic acid 3-0-mono-b-D-glucuronide and related glycosides, Biosci. Biotechnol. Biochem., 58 (1994) 554-555.

23. I. Kitagawa, Licorice root. A natural sweetener and an important ingredient in Chinese medicine, Pure Appl. Chem., 74 (2002) 1189-1198.

24. M. Dervisoglu and F. YazıcI, The effect of citrus fibre on the physical, chemical and sensory properties of ice cream, Food Sci. Technol Int., 12 (2006) 159-64.

25. C. Özdemir, E. Dagdemir, S.. Çelik, S. Özdemir, An alternative ice cream production for diabetic patients, Milchwissenschaft., 58 (2003) 164-166. 